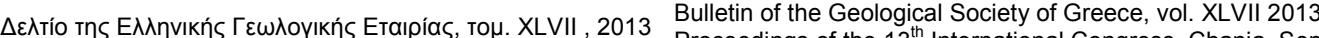
Proceedings of the $13^{\text {th }}$ International Congress, Chania, Sept.

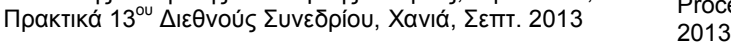

\title{
BIOSTRATIGRAPHICAL AND SEDIMENTOLOGICAL STUDY OF AN UPPER CRETACEOUS SUCCESSION IN THE SAMI AREA (CENTRAL AREA OF KEFALLINIA, W. GREECE)
}

\author{
Zoumpouli E. ${ }^{1}$, Pomoni-Papaioannou F. ${ }^{2}$, Zelilidis A. ${ }^{1}$ and Iliopoulos G. ${ }^{1}$ \\ ${ }^{1}$ University of Patras, Department of Geology, Laboratory of Sedimentology, 26500, Patras, \\ Greece,elzoumpouli@upatras.gr,a.zelilidis@upatras.gr,iliopoulosg@upatras.gr \\ ${ }^{2}$ Department of Geology and Geoenvironment, Section of Historical Geology and Palaeontology, \\ National University of Athens, Panepistimiopolis, 15784 Athens, Greece,fpomoni@geol.uoa.gr
}

\begin{abstract}
On the island of Kefallinia, which lies at the external edge of the Hellenides fold and thrust system, appear the Paxi and the Ionian Zones. In this study, an Upper Cretaceous carbonate succession, which is a part of the Paxi Zone, cropping out near the area of Sami (central area of Kefallinia), is discussed in detail with regard to its depositional facies, microfacies, biostratigraphy and palaeoenviroments. Detailed sedimentological and palaeontological investigations have been carried out on seven sections and petrographic analysis of thin-sections that led to the recognition of a number of microfacies types grouped into four facies zones. There was recorded a supratidal-intertidal (restricted)-intertidal (open lagoon)- subtidal (or shallow subtidal) vertical transition. Supratidal facies are characterized by fenestral and peloidal wackestone / packstone, intertidal (restricted) facies are represented by bioclastic wackestone and bindstone, whereas intertidal (open lagoon) facies are indicated by bioclastic packstone. Finally subtidal facies are dominated by bioclastic floatstone and grainstone. Benthic foraminifera are especially abundant and along with calcareous algae are the most important fossils used for age determination. The benthic foraminiferal genera that were identified (Cuneolina sp., Quinqueloculina sp., Nezzazata sp., Pseudonummoloculina sp., Dicyclina sp.), in addition with the observed calcareous algae, rudist and gastropods provide significant data for the depositional environments and the paleoecology of the Paxi Zone during the Upper Cretaceous.
\end{abstract}

Key words: Upper Cretaceous microfacies, Paxi Zone, Benthic foraminifera.

\section{Пєрí $\lambda \psi \eta$}

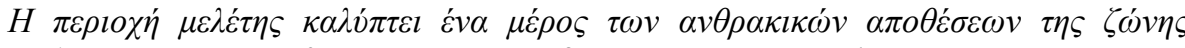

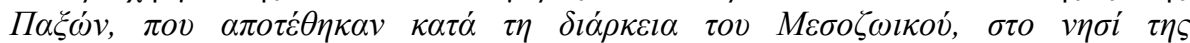

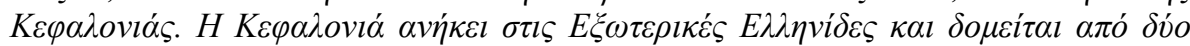

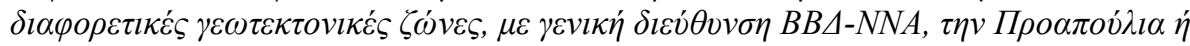

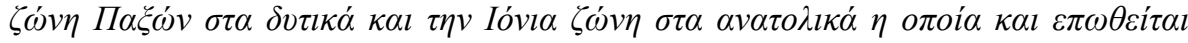

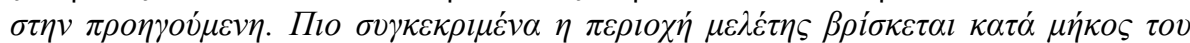

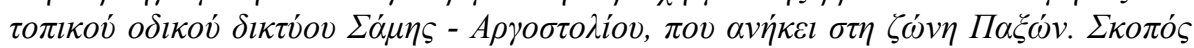

XLVII. No $1-226$ 


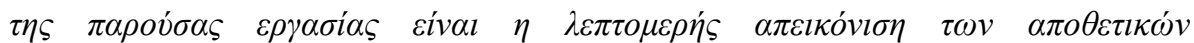

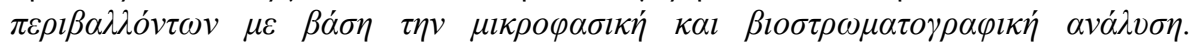

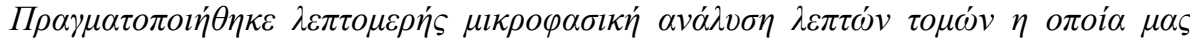

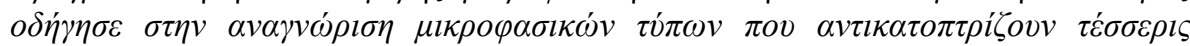

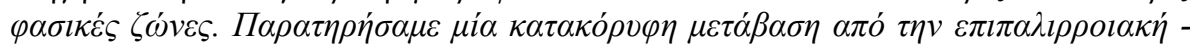

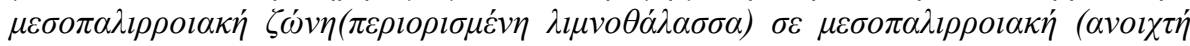

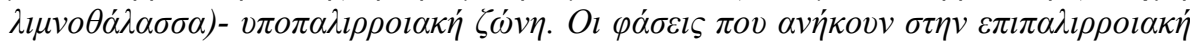

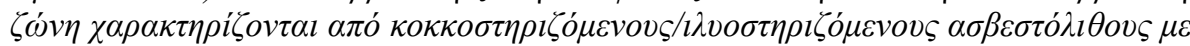

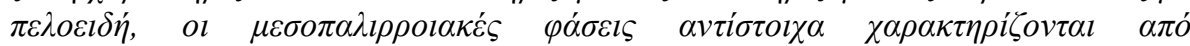

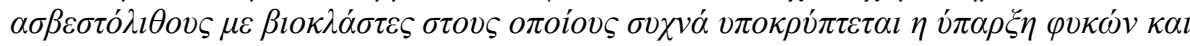

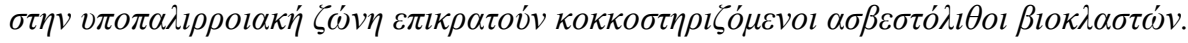

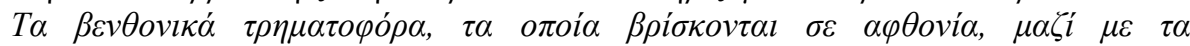

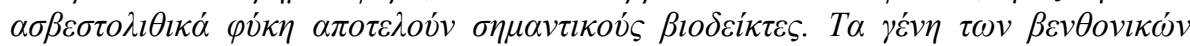

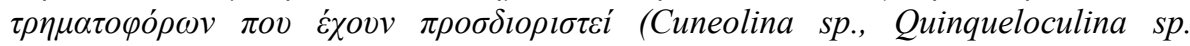
Nezzazata sp., Pseudonummoloculina sp., Dicyclina sp.) $\sigma \varepsilon \sigma v v \delta v \alpha \sigma \mu o ́ ~ \mu \varepsilon \tau \eta v$

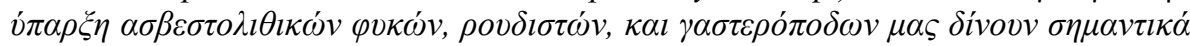

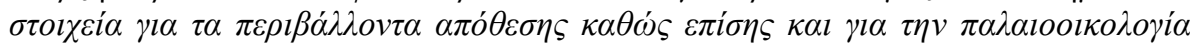

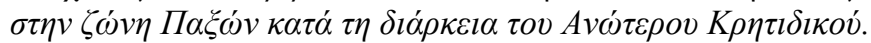

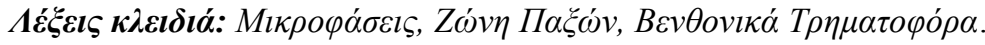

\title{
1. Introduction
}

Sedimentological and paleontological studies have carried out on an Upper Cretaceous shallowwater carbonate succession near the area of Sami (central Kefallinia Figure 1), which is a part of the of the Paxi zone. The Apulian platform is one of the Bahama-type platforms created on the Tethys passive southern continental margin. Paxi zone is the transitional zone (slope) between the Apulian platform and the Ionian basin (Nikolaou, 1986; Accordi et al., 1998; Karakitsios and Rigakis, 2007). By studying the carbonate unit of the Sami stratigraphic section we attempted to understand the depositional setting and to distinguish between subtidal, intertidal and supratidal carbonates, by focusing on diagnostic criteria using microfacies and micropaleontological analysis (Flügel, 2004).

The high-resolution stratigraphic analysis has shown a number of lithofacies organized in groups (lithofacies associations), suggesting, on the whole, sedimentary environments ranging from lagoonal to peritidal context. The peritidal deposits are easy to be recognized in outcrops and in thin sections. They are important paleo-bathymetric indicators, reflecting sea-level fluctuations (Flugel, 2004; Brescia et al., 1996; D’Argenio et al., 1997, 1999).

In many cases, the sedimentary structures and the great abundance of bioclasts are indicative of depositional environments. Especially benthic foraminifera have been taken into consideration in order to enhance the environmental interpretation provided by lithofacies. It is well known that, as the fossil accumulations are important sources of paleontological and paleoenvironmental data, the taphonomic and sedimentological characteristics of the fossils assemblages reflect the dynamic environmental conditions. Furthermore, the study of fossil concentrations is critical for the reconstruction of the long- term, as well as of the short-term, environmental variation and, as a consequence, for the interpretation of depositional sequences and sea-level changes.

The objective of this paper is to establish a detailed analysis of the vertical variations of the microfossils associations in relation with the distribution of the lithofacies. The study is based on seven stratigraphic sections extending along $4 \mathrm{~km}$, with thickness averaging $400 \mathrm{~m}$. In total, 150 samples have been collected for centimetre scale microfacies analysis. 


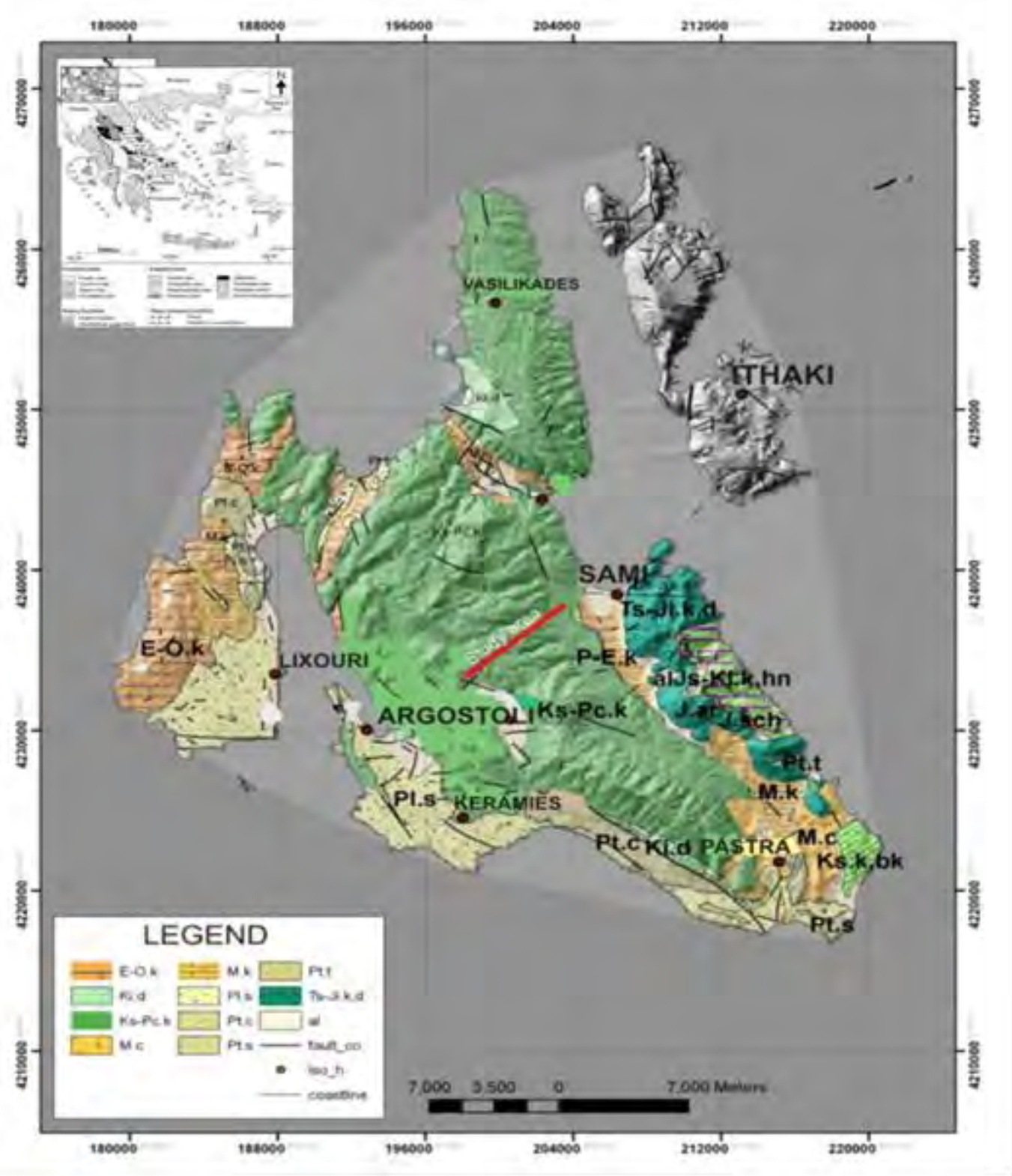

Figure 1 -Kefallinia Island. Geological map of Kefallinia showing the studied cross section.

\section{Geological Setting}

Kefallinia lies at the external (foreland) edge of the Hellenides fold-and-thrust system created in response to Cenozoic continental collision following closure of the Tethyan Ocean. The external Hellenides lie to the west of the Pindos thrust and are subdivided into three isopic zone: GavrovoTripolitza, Ionian, and Paxi zones. The Gavrovo-Tripolitza and the Ionian zones have been considered to represent the external large Hellenide thrust sheets emplaced onto the relatively stable Paxi autochthon, as a part of the latest Hellenide events (Aubouin and Dercourt, 1962; Jenkyns, 1968; Smith and Moores, 1974; Underhill, 1989). 
During the Early Mesozoic times, an extensive rifting had been developed in the western Greek territory, which in Early-Middle Jurassic times, was subdivided into ridges and basins, that corresponded to the Gavrovo and Apulian platforms and the Ionian basin respectively. Paxi zone is the slope between the Apulian platform and the Ionian basin. Post-rift sedimentation persisted throughout the Cretaceous leading to shallow marine carbonates on the ridges, mixed pelagic/neritic sedimentation on the slope (Paxi zone) and deep-water carbonates in the basin (Karakitsios, 1992; 1995; Getsos, 2005; Getsos et al., 2007).

From the Triassic to the Upper Cretaceous, Western Greece was part of the Apulian continental block on the southern passive margin of Tethys. The island of Kefallinia is characterized by widely exposed Cretaceous limestones of the Paxi and Ionian zones, which were deposited at the margin of the Apulian carbonate platform. The Paxi zone consists of Triassic to Miocene deposits, mainly neritic carbonates. The Ionian zone comprises sedimentary formations ranging from Triassic evaporites to Jurassic- Upper Eocene carbonates, including minor cherts and shales, overlain by Oligocene flysh (Karakitsios and Rigakis, 2007).

The Paxi zone forms the major part of the island of Kefallinia. It has been regarded as being the autochthonous foreland of the Hellenide fold-thrust belt, which is generally believed to have been unaffected by major shortening (Aubouin, 1965; Jones, 1968; British Petroleum Co. Ltd., 1971; Smith and Moores, 1974; Underhill, 1989).

Sami lies immediately to the west of the Ionian thrust and is composed entirely of thick Upper Cretaceous limestones that have been folded into a broad, open, northwest-southeast - trending pericline. The studied sections belong to the Paxi zone and lie across the main road of SamiArgostoli where well exposed outcrops occur (Figure 1).

\section{Materials and Methods}

The Upper Cretaceous carbonate succession in Sami is characterised by excellent outcrops, which are commonly characterised by wide lateral extents of several hundreds of metres. This outcrop situation allowed detailed field studies concentrating on lithology, sedimentary structures, and sequence-stratigraphic patterns. Five sections were analysed with regard to microfacies, biostratigraphy, and sequence stratigraphy and were correlated in detail. The sections were sampled very closely, the distance between two samples being less than $10 \mathrm{~cm}$ in important intervals, but reaching a few metres in more uniform intervals. Microfacies analyses of samples were performed on about 300 thin sections representing various shallow water microfacies types. Determination of stratigraphic position of the investigated succession is based on the identification of microfossils assemblages (benthic foraminifera and calcareous algae Dasycladales) and on using their taxa as index fossils.

Shallow-marine bedded carbonate sequences need a detailed sampling program, because they exhibit high microfacies variability due to changing subtidal and tidal depositional sites and common occurrence of cyclic sedimentation patterns.

In the studied succession, the high-resolution stratigraphic analysis has shown a number of lithofacies organized in groups. The vertical arrangement of these lithofacies allows the identification of a cyclic recurrence of the depositional and early diagenetic features, including a meteoric overprint that may be observed on top of the elementary cycles.

\section{Biostratigraphical Observations}

Biostratigraphic interpretation of the mainly shallow-marine Upper Coniacian to Lower Campanian deposits is based on benthic organisms. Benthic foraminifera assemblages are the signal biostratigraphical tool for subdivision of the Cretaceous platform carbonate succession. Ranges of the foraminiferal taxa recognized in the Sami Cretaceous sections are shown in Figure 
2. Benthic foraminiferal taxa are represented by Quinqueloculina sp. D'Orbigny, Cuneolina sp. D’Orbigny, Dicyclina sp. Munier-Chalmas, Pseudonummoloculina sp. Spiroloculina sp. D’Orbigny, Moncharmontia sp. De Castro and Nezzazata sp. Omara The determined assemblage include, except for the benthic foraminifera, Thaumatoporella, Dasyclad green algae, Rudist in shell debris and Ostracods. Gastropods occur locally and sporadically. Generic attributions of the benthic foraminifers' taxa are based on Loeblich\& Tappan, 1988 classification. A compilation of the most important taxa and their biostratigraphic ranges for the studied area is given below, in Figure 2.

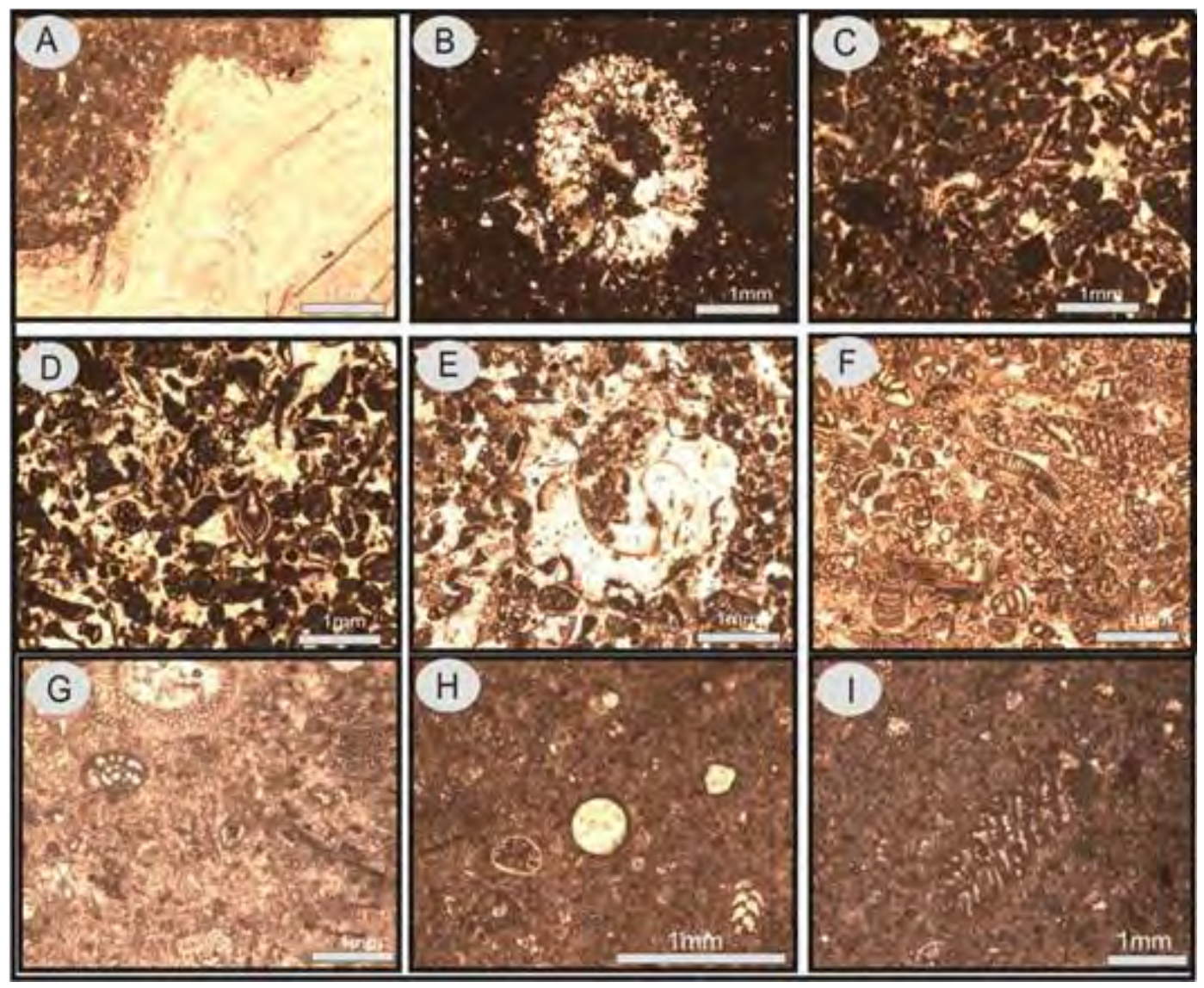

Figure 2 - A)Rudist, B)Dasyclad green algae, C)Quinqueloculina sp., Dicyclina sp., D) Spiroloculina sp. Pseudonummoloculina sp., Quinqueloculina sp. E) Gastropods \& Miliolidae, F) Cuneolina sp., Pseudonummoloculina sp., Dicyclina sp., Nezzazata sp., Quinqueloculina sp., G) Thaumatoporella sp., Moncharmontia sp., H) Thaumatoporella sp., Ostracods, I) Dicyclina sp.

\section{Lithofacies and Paleoenviromental Interpretation}

This carbonate platform is represented by a monotonous succession of cream coloured, medium to thick-bedded (10-40 cm) limestones (Figure 3). The most common lithofacies are wackestone/mudstone with thin shelled ostracods and Thaumatoporella, laminated packstone with contribution of benthic foraminifera, grainstone with benthic foraminifera and finally floatstone with Rudist debris occur sporadically.

Five Standard Microfacies Types can be distinguished (Pomoni-Papaioannou et al., 2012): 
- $\quad$ SMF 9 represented by bioclastic wackestone/floatstone with various shells.

- SMF 18 represented by packstone/grainstone benthic foraminifera with abundant miliolids and calcareous green algae. Miliolid foraminifera are very common in lagoonal environments, restricted inner platforms and inner ramps.

- SMF 18 b represented by bioclastic packstone/floatstone. Fossils are fragments of benthic foraminifera, Rudist, Gastropods or Dasycladacea. Bedded limestones with larger foraminifera and molluscs represent the shallow part of the lagoon. The composition of the gastropod fauna reflects changes from open marine to more restricted conditions.

- SMF 19 represented by bindstone with laminated fabric consisting of millimetre thick laminae. SMF type 19 is often used as indicator for intertidal and supratidal environments. The main criteria are lamination textures caused by microbial/ algal mats and fenestral fabrics.

- SMF 20 and SMF 21 are also used as indicators for intertidal and supratidal environments. The main criteria are lamination textures caused by microbial/algal mats and fenestral fabrics.

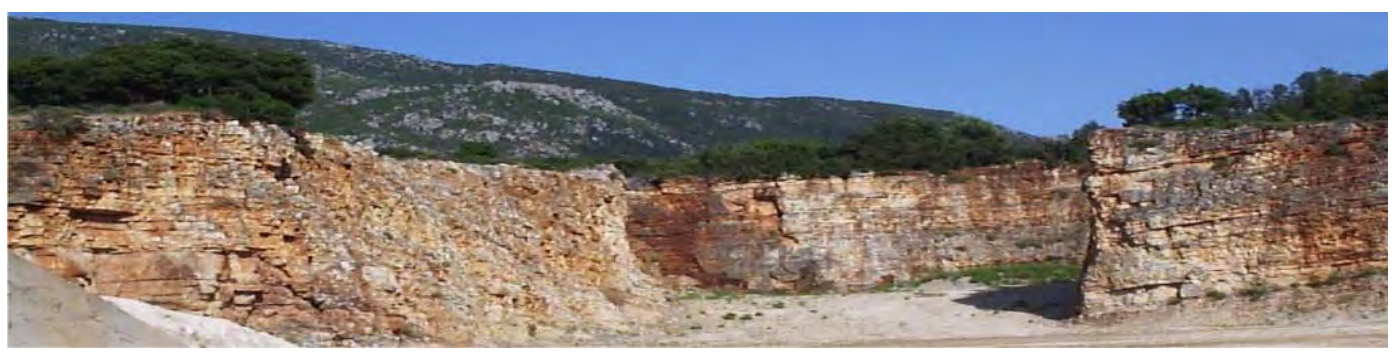

Figure 3-Sami section: A typical peritidal carbonate unit.

The diagnostic criteria of the Standard Microfacies indicate two different Facies zones of the Wilsons' model, FZ 7 which represents a shallow open-marine platform and FZ 8 which represents a restricted marine platform (Table 1). Particularly, Facies zone FZ 7 includes SMF 9 and sporadically SMF 18. Respectively, FZ 8 includes SMF 18, SMF 18b, SMF 20 and SMF 21.

The specific biostratigraphical and sedimentological characteristics of the recognized Facies zones are the following:

\section{FZ 7 Open- marine platform}

Setting: Flat platform top within euphotic zone, normally above fair-weather wave base.

Lithofacies/Biota: SMF 9 mudstone/wackestone with Thaumatoporella, Ostracods, Rudist, Benthic foraminifera as Quinqueloculina sp., Moncharmontia sp. and SMF 18 packstone/grainstone with peloids and benthic foraminifera (Mililolidae (Quinqueloculina sp.))

\section{FZ 8 Restricted-marine platform}

Setting: Platform less well connected with the open ocean which is within the ephotic zone and represents shallow, cut-off ponds and lagoons with restricted circulation and hypersaline water.

Lithofacies/Biota: SMF 18 Packstone/grainstone with peloids and benthic foraminifera (Quinqueloculina sp., Dicyclina sp., Cuneolina sp., Spiroloculina sp. Pseudonummoloculina sp.), SMF 18b floatstone with large intraclast as Gastropods, Dasycladacea or Rudists and benthic foraminifera ((Quinqueloculina sp., Dicyclina sp., Cuneolina sp., Spiroloculina sp.), SMF 19 densely laminated bindstone, SMF 20 Laminated stromatolitic bindstone and finally SMF 21 fenestral packstone and bindstone. 
The predominance of mud-rich lithologies with oligotypic fauna (ostracods, algae and miliolidae) and the presence of a low diversity foraminiferal association indicate a restricted platform (Pomoni-Papaioannou, 2008, Pomoni-Papaioannou \& Kostopoulou, 2008), very shallow lagoon with low to moderate hydraulic energy, subjected to periodic emersions (fenestrae). Upwards, the succession consists of limestones enriched in benthic foraminiferal but still characterized by a low diversity. The dominance of miliolidae and the presence of algal laminations indicate a very shallow lagoon with moderate to high hydraulic energy (restricted platform, intertidal to shallow subtidal). Occasionally, open-marine influence is confirmed by the presence of floatstone with Rudist shell fragments associated with a comparatively diverse benthic foraminiferal assemblage.

Small-scale cycles, formed in a low-energy peritidal environments are characterized by the repetitive stacking of the facies types which are presented in Figure 4.

Table 1 - Sami Section: lithofacies associations.

\begin{tabular}{|c|c|c|}
\hline Facies Zone & Microfacies & Discription \\
\hline \multirow[t]{2}{*}{$\begin{array}{l}\text { FZ } 7 \text { Open-marine } \\
\text { platform }\end{array}$} & SMF 9 & $\begin{array}{l}\text { Mudstone/wackestone with } \\
\text { Thaumatoporella, Ostracods, Rudist, } \\
\text { Benthic foraminifera (Quinqueloculina sp., } \\
\text { Moncharmontia sp.) }\end{array}$ \\
\hline & SMF 18 & $\begin{array}{l}\text { Packstone/grainstone with peloids and } \\
\text { benthic foraminifera ( Mililolidae } \\
\text { (Quinqueloculina } \mathrm{sp} . \text { )) }\end{array}$ \\
\hline \multirow[t]{5}{*}{$\begin{array}{l}\text { FZ } 8 \text { Restricted-marine } \\
\text { platform }\end{array}$} & SMF 18 & $\begin{array}{l}\text { Packstone/grainstone with peloids and } \\
\text { benthic foraminifera (Quinqueloculina sp., } \\
\text { Dicyclina sp., Cuneolina sp., Spiroloculina } \\
\text { sp. Pseudonummoloculina sp.) }\end{array}$ \\
\hline & SMF 18b & $\begin{array}{l}\text { Floatstone with large intraclast as } \\
\text { Gastropods, Dasycladacea or Rudists and } \\
\text { benthic foraminifera ((Quinqueloculina } \\
\text { sp., Dicyclina sp., Cuneolina sp., } \\
\text { Spiroloculina sp.) }\end{array}$ \\
\hline & SMF 19 & Densely laminated bindstone \\
\hline & SMF 20 & Laminated stromatolitic bindstone \\
\hline & SMF 21 & Fenestral packstone and bindstone \\
\hline
\end{tabular}




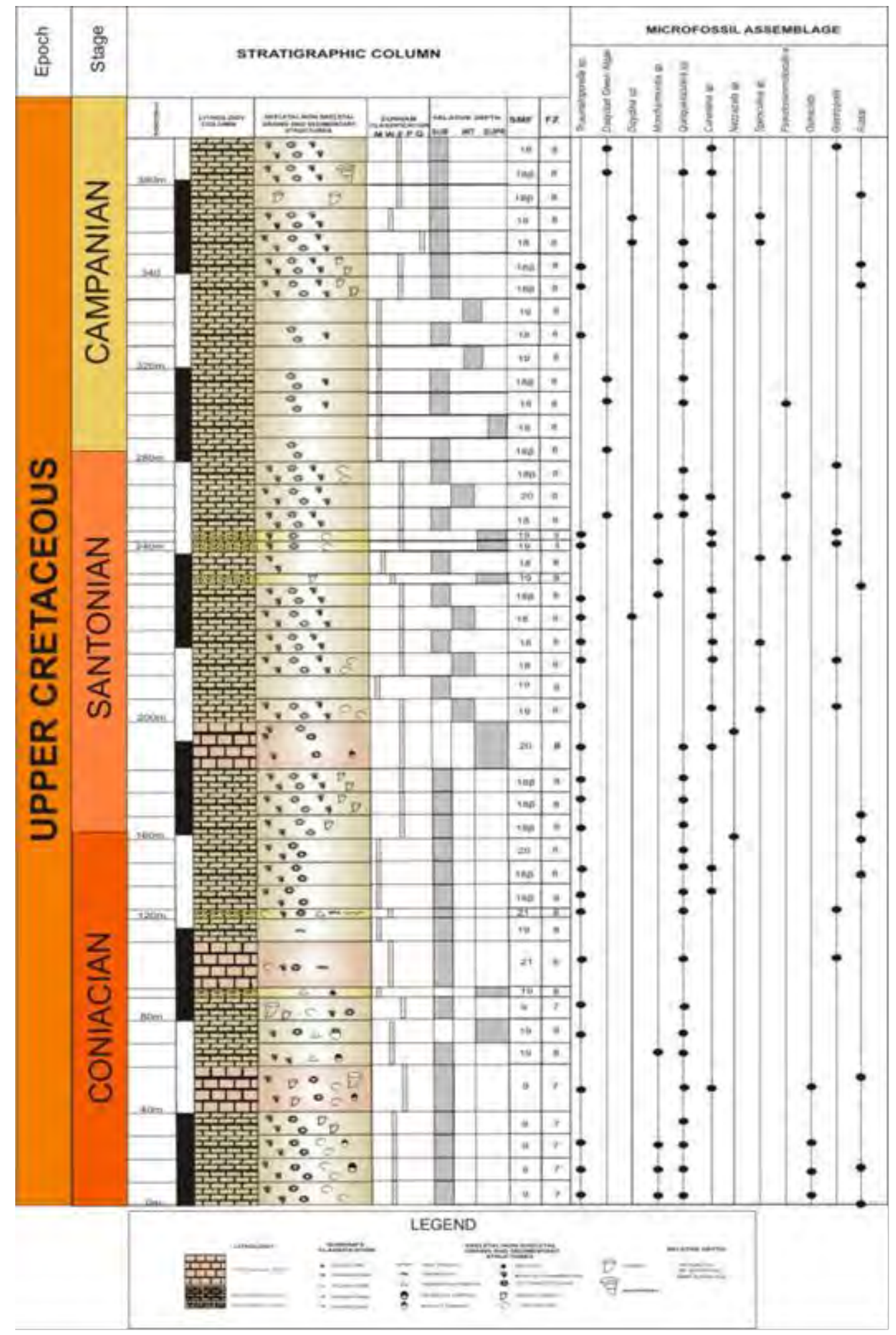

Figure 4 - Stratigraphic column of the Upper Cretaceous carbonate sequence of the Sami area.

$\underline{\text { XLVII. No } 1-233}$ 


\section{Conclusions}

The combination of biostratigraphic and stratigraphic correlation of the studied Upper Coniacian to Lower Campanian succession allows us to interpret the depositional environments of the carbonate succession of the Paxi zone in the Sami area. The data presented in this paper illustrates that Paxi zone, during the Upper Cretaceous, was tectonically controlled. Sami area represents an uplifted part of this slope, exhibiting shallow water deposits, while others are characterized by mixed pelagic/neritic sedimentation. The high-resolution stratigraphic analysis has shown a number of lithofacies organized in groups (lithofacies associations), suggesting, on the whole, sedimentary environments ranging from lagoonal to peritidal context.

\section{References}

Aubouin J. 1962. Zone preapulienne et zone du Gavrovo en Peloponnese occidental, Bulletin de Société Geologique de la France, v.4, 785-794.

Accordi G., Carbone, F. and Pignatti J. 1998. Depositional history of a Paleogene carbonate ramp (Western Cephalonia, Ionian Islands, Greece), Geologica Romana 34: 131-205.

Brescia M., D’Argenio B., Ferreri V., Pelosi N., Rampone S. and Tagliaferri R. Neural net aided detection of astronomical periodicities in geologic records, Earth Planet. Sci. Lett., v.139, 33-45.

Buonocunto F.P., D’Argenio B., Ferreri V. and Raspini A. 1994. Microstratigraphy of highly organized carbonate platform deposits of Cretaceous age, The case of Serra Sbregavitelli (Matese, central Apennines), Giorn. Geol., 56, 179-192.

Flügel E. 2004. Microfacies Analysis of Carbonate Rocks, Springer Verlag, Berlin, 745pp.

Getsos K., 2005. Ionian basin analysis and its evolution,during the Triassic-Paleogene time interval and the relation with hydrocarbon plays, $P h D$ Thesis, University of Patras.

Getsos K., Pomoni-Papaioannou F. and Zelilidis A. 2007. A carbonate ramp evolution in the transition from the Apulia platform to the Ionian basin during Early to Late Cretaceous (NW Greece), Proceedings of the $11^{\text {th }}$ Intern. Congress of the Geological society of Greece, Bull of the Geol.Soc. Greece, v. XXVII, 53-63.

Jenkyns D.A.L. 1972. Structural development of western Greece, American Association of Petroleum Geologists Bulletin, v. 56, 128-149.

Jones W.D.V. 1968. Results of recent geological surveys in central-western Greece, Geological Society of London. Proccedings, v. 1645, 306-310.

Karakitsios V. and Rigakis N. 2007. Evolution and petroleum potential of western Greece, Journal of Petroleum Geology, v. 30(3), 197-218.

Loblich A. and Tappan H. 1988. Foraminiferal Genera and their classification, Copyright@ Van Nostrand Reinhold.

Pomoni-Papaioannou F. 2008. Facies analysis of the Lofer cycles (Upper Triassic), in Argolis Peninsula (Greece), Sedimentary Geology, v. 208, 79-87.

Pomoni-Papaioannou F. and Kostopoulou V. 2008. Microfacies and cycle stacking pattern in Liassic peritidal carbonate platform strata, Tripolitza-Gavrovo platform, Greece, Facies, $54,417-431$.

Pomoni-Papaioannou F., Zoumpouli E., Zelilidis A. and Iliopoulos G. 2012. Microfacies and benthic foraminiferal assemblages of the carbonate succession of the Cretaceous platform in the Sami area (NW of Kefallinia, W Greece): Biostratigraphy and palaeoenvironments, $29^{\text {th }}$ IAS Meeting of Sedimentology. Schladming, Austria on $10^{\text {th }}-13^{\text {th }}$ September 2012, Abstract (Poster).

Smith A.G., and Moores E.M. 1974. Hellenides, in Spencer-Verlag. Mesozoic and Cenozoic orogenic belts, Geological Society of London Special Publication, v. 4, 159-185.

Underhill J. 1989. Late Cenozoic deformation of the Hellenide foreland western Greece, Geological Society of America Bulletin, v. 101, 613-634. 